\section{CHROMOSOME BREAKERS}

Actions of Chemicals on Dividing Cells

By Bengt A. Kihlman. (Prentice-Hall Biological Science Series.) Pp. xi + 260. (Englewood Cliffs, N.J., and London: Prentice-Hall, 1966.) $60 s$.

Since the discovery in 1928 that $\mathrm{X}$-rays produce gene and chromosome mutations there has been a search for chemical agents with mutagenic properties. The chief aim has been to use chemicals to get a better understanding of the molecular organization of chromosomes and of the mechanism by which heritable material is permanently altered. The discovery in the early forties that ethyl urethane and the vesicant mustard gas have mutagenic properties stimulated further search for similar chemical agents which could be used, as are X-rays, to treat malignant disease. Since 1950, the number of such chemical agents has increased considerably and their effects have been described in numerous articles. Kihlman is an expert who is well suited to review the progress
of this field.

The scope of his book is restricted to a description of the "harmful effects" on dividing cells of a few chemical agents, some of which are used in medicine and agriculture. The discussion of the effects produced by these agents is further limited; only two metabolic processesoxidative phosphorylation and DNA synthesis-are considered. Kihlman's information has been mainly obtained from studies of cells cultured in vitro or pro. liferating in the root-tip of the broad-bean (Vicia). The reader will find that the biochemical process by which these agents produce their effects is still unclear. In the final chapter the author concludes "that to explain the mechanism of chromosome breakage we must know more about the structure and organization of the interphase ehromosome".

The book contains a mass of valuable information on chemical agents. Kihlman has selected this information carefully, and its synthesis is an achievement which will help anyone involved in studying chemical mutagenesis. The first part of the book deals with the interphase cell, the mitotic cycle, and the structure and biosynthesis of DNA. The second part describes the various types of chromosome aberration and enumerates the twenty-two chromosome breaking chemicals (including DNA precursors, antibiotics, alkylating agents and nitrosocompounds) which produce such aberrations. Another chapter discusses the chemical and physico-chemical properties of the chromosome breaking agents thought to be responsible for the cytological effects. The sixteen chapters are well supplied with illustrations, graphs and tables, and the bibliography includes more than five hundred references.

P. C. KOLLER

\section{MARINE MISCELLANY}

\section{Some Contemporary Studies in Marine Science}

Edited by Harold Barnes. Pp. 716. (London: George Allen and Unwin, Ltd., 1966.) 147s. net.

Anyone attempting to study the biology of the marine plankton would not get far into the literature before becoming aware of the notable contribution made to this field by Sheina Marshall and the late A. P. Orr. This book is a collection of papers presented to Dr. Marshall on her official retirement by her friends and colleagues, as a tribute to her long and successful collaboration with Dr. Orr.

In a presentation volume the editor has a considerable responsibility to see that the book is well produced and forms a significant contribution to scientific literature, for it is the success of the book that will constitute the greatest compliment to those to whom it is dedicated. That the book fails in these two respects is largely a matter of editorial policy which it is relevant to examine in more detail. Except for the title, little effort has been made to attract the casual reader. Apart from published symposia, one does not normally expect to buy a collection of scientific papers on a variety of topics loosely associated with marine science. As a form of literature, the average scientific paper is not interesting reading except to specialists. Here the reader is faced with details of biochemical analyses, a Latin diagnosis, and numerous lists and tables which are essential to the papers but can only be read by a determined effort. Surely the proper place for this type of communication is in the journals, and it is the scientific essay or review which is most suited to a book of this kind.

It is only fair to record that those authors who adopt this style have produced informative and readable contributions. J. A. Allen has summarized his published work on the population dynamics of the Caridea off the Northumberland coast, and R. B. Clark has given an interesting and closely reasoned contribution on the development of neurosecretion in both vertebrates and invertebrates. There are fourteen papers on planktonic crustacea, and that by D. T. Gauld on the swimming and feeding of copepods is a clear and comparative exposition on this subject. G. A. Horridge discusses recent work on the sense organs of marine invertebrates with particular reference to the detection of small underwater vibrations which may be important in their feeding behaviour.

My criticism of the style adopted for the majority of the articles must not be taken to imply criticism of their scientific content. Many of the papers are of a high standard and would find ready acceptance in the appropriate journal. Indeed, consultation of the references indicates that the substance of many of the papers has already been published, despite the claims to originality on the dust jacket of the book.

Universities and institutional libraries will probably require a copy of this book, but at this price I cannot recommend buying a personal copy.

Derek DorsetT

\section{BOTANICAL EXPLORATION}

\section{Chapters on the History of Botany in India}

By I. H. Burkill. Pp. xi + 245. (Delhi: Manager of Publications, 1965.) Rs. 5.50; 12s. 10d.; \$1.98.

I. H. BurkiLl had a most distinguished career in the tropies, first for 12 years in the Botanical Survey of India, and second, for a further 13 years, as Director of the Botanical Garden, Singapore. Always a fanatic for order and method, Burkill never failed to note down on slips of paper items of information which interested him, and these were carefully filed away under various headings. One of these was "Useful Tropical Plants" and another "Botanical Exploration in India". From the 36,000 entries under the former heading came the monumental Dictionary of the Economic Products of the Malay Peninsula. The latter, also many thousands, provided the groundwork for the present book.

This is, as the author modestly states in his introdue. tion, an attempt to put on record the names of all those who have earned recognition by introducing botany into India. No "attempt" is complete, but Burkill's book gives an overall picture of botanical exploration in India which is not likely to be bettered. His story begins with Garcia da Orta in 1490 and ends more or less at the end of the nineteenth century.

As the narrative unfolds itself in orderly sequence, one is astonished at the wide reading of the author, his often critical and apt comment and the frequent deft reference to some event in a collector's life which illustrates a point.

This is no arid list of names and dates but contains many thumbnail biographies of persons who are to so many 